\title{
SELF-IDENTIFICATION OF POLISH ACADEMIC ECONOMISTS WITH SCHOOLS OF ECONOMIC THOUGHT*
}

\author{
Grzegorz KONAT - Wanda KARPIŃSKA-MIZIELIŃSKA - Kazimierz KLOC - \\ Tadeusz SMUGA - Bartosz WITKOWSKI
}

(Received: 4 January 2018; revision received: 21 May 2018;

accepted: 17 July 2018)

\begin{abstract}
The paper presents the results of a research conducted in 2014-2016, aimed at characterising the milieu of the Polish academic economists with respect to their self-identification with modern schools of economic thought. Using econometric modelling, the social variables determining the theoretical choices made by the economists themselves were identified. We found that the largest group of the Polish academic economists identifies themselves with new institutional economics. Nearly half of the respondents declared their association with heterodox approaches, while only about a quarter of the respondents showed association with economic orthodoxy. Such a structure of self-identification of the Polish academic economists with schools of economic thought distinguishes it from the ones in other European countries, such as Italy and Germany.
\end{abstract}

Keywords: schools of economic thought, academic economists, economics in Poland, scientific self-awareness, survey research

JEL classification indices: A14, B41, B50

* This research was a part of the project entitled "The Identification of Polish Academic Economists with Schools of Economic Thought", funded by the National Science Centre (No. UMO2013/09/B/HS4/02706) and carried out in the Socio-Economic Research Unit of the Institute for Market, Consumption and Business Cycles Research in Warsaw.

Grzegorz Konat, corresponding author. Researcher in the Agricultural Finance Department, Institute of Agricultural and Food Economics - National Research Institute, Warsaw, Poland. E-mail: grzegorz.konat@ierigz.waw.pl

Wanda Karpińska-Mizielińska, Emerita, Socio-Economic Research Unit, Institute for Market, Consumption and Business Cycles Research - National Research Institute, Warsaw, Poland. E-mail:wmizielinska@gmail.com

Kazimierz Kloc, Professor in the Institute of Political Economy, Law and Economic Policy, Collegium of Management and Finance, Warsaw School of Economics, Warsaw, Poland.

E-mail: kazimierz.kloc@sgh.waw.pl

Tadeusz Smuga, Emeritus, Socio-Economic Research Unit, Institute for Market, Consumption and Business Cycles Research - National Research Institute, Warsaw, Poland.

E-mail: tsmuga@interia.pl

Bartosz Witkowski, Professor in the Institute of Econometrics, Collegium of Economic Analysis, Warsaw School of Economics, Warsaw, Poland. E-mail: bartosz.witkowski@sgh.waw.pl 


\section{INTRODUCTION}

In the last decades of the $20^{\text {th }}$ century, academic economics in Poland underwent a considerable transformation. The primary cause was a disruptive shift in Poland's economy that began in 1989, which resulted in yet another case of discontinuity in the Polish economic science taking place in the $20^{\text {th }}$ century. In the past, such a sudden shift took place in 1949 and was related to political and economic changes occurring after World War II, in particular to the acquisition of power by the Communist Party. The aftermath of the formation of a centrally planned economy in Poland was the rejection of the economic concepts and schools which were not rooted in the Marxist economics in the form that developed at the time in the Soviet Union.

In the 1950s, a new generation of researchers were being taught concepts from textbooks and formulas influenced by the theories of Soviet science. From the second half of the 50s, the Marxist economics in Poland began developing independently, and gradually moving away from simply reproducing the Soviet formulas. However, despite its diversity, the Polish economic thought continued to remain grounded within the framework of broadly defined Marxist theory. This persisted until the next systemic transformation, which took place in the late $80 \mathrm{~s}$. This transformation influenced the mind-sets and analytical methods of the Polish economists, particularly through the rejection of old concepts and the adoption of new theoretical approaches. This shift in economic theory was reflected by moving away from the Marxist theory and moving towards the neoclassical and Keynesian traditions.

These changes were a product of not only the political transformation, but also of the processes of globalisation and the rise of information technology. Effects of the latter include widespread access to international research, as well as the changes in the structure and functioning of the Polish universities. These processes are correlated with such developments as increased competition in the education market, as well as the creation of private economic universities not only in the established academic centres, but also in smaller towns with no prior background in the field. As a result, researchers are being recruited from countless different economic centres, and personnel often have vastly disparate professional backgrounds and methodological standards.

The status of the Polish research raises questions concerning the current position of the Polish academic economists, particularly in the context of their preferred economic theories. Our study is an attempt at providing a response to these questions. Its goal is to analyse the way the Polish academic economists perceive their own affiliation to specific schools of economic thought. Additionally, it aims to identify such demographic and social variables as association with 
particular social groups, economic education, career path, etc. which determine their theoretical choices.

The structure of this paper is as follows: The second part is a review of the literature, which examines the relevant research carried out by the economists to date. Section 3 is devoted to the methodology of classifying schools of economic thought and theoretical choices, as well as detailing the obstacles which we encountered along the way. Section 4 presents the findings of the survey. Particular attention is paid to the schools of economics that the respondents self-identified with, the internal consistency of the respondents' views, and the variables determining these views (through the application of econometric models). The final part of the paper summarises the key findings.

\section{LITERATURE REVIEW}

There has been a distinct lack of in-depth empirical research focusing on the academic economists in Poland, including any analysis of their approach to and perception of the economy or their own occupational group. So far, the only relevant studies have been regularly conducted opinion polls examining economists' views regarding the government's economic policies (Rozwój... 2014). These polls aim to gather the opinions of economists (both scientists and employees of financial institutions) on particular actions undertaken as a part of government's economic policy, evaluation of its quality and formulating relevant recommendations for the future.

It seems safe to assume that to date, the United States has conducted most of the opinion poll studies on economists, the majority of which examined the members of the American Economic Association (AEA). ${ }^{1}$ The respondents were asked to express their political views and/or positions on economic and social policy issues, and occasionally their thoughts on specific theoretical concepts (see e.g. Alston et al. 1992; Fuller - Geide-Stevenson 2003; Klein - Stern 2006; Whaples 2006). These researches also included a distinct subgroup of studies that focused on specific economic sub-disciplines, such as economic historians (Whaples 1995), public choice economists (Whaples - Heckelman 2005), labour economists (Whaples 1996) or industrial organisation economists (Aiginger et al. 2001).

AEA members include not only academic economists but also individuals who fall into the broader category of business practitioners, representing both the public and the private sector. There is a methodological difference between the American and our research, mainly regarding selecting survey participants. Our sample was more homogeneous and included only the economists who held at least a $\mathrm{PhD}$ degree and who were employed either at the university or research institutes. 
Analyses of economists' affiliation with particular schools of economic thought have been conducted mainly in Europe. In Germany (Frey et al. 2010), even though most of the surveyed economists declared themselves as preferring neoclassical economics, the results pointed to a general acceptance among the respondents for less orthodox schools of thought. Interestingly, in a study carried out in 2007 about the economists employed in the universities in Italy, respondents would most commonly describe themselves as eclectics (28\%) (Di Maio 2013; De Benedictis - Di Maio 2011, 2014). ${ }^{2}$

\section{METHODOLOGICAL ISSUES}

As defined by the methodology of science, a 'school' is characterised by a common area of research, shared terminology, issues, methodological preferences and formulated hypotheses. However, in the sociology of knowledge, the term 'school' represents a group associated with an authority or work, characterised by interdependencies and a common language to describe examined phenomena (Karpiński 2006). For the purposes of this study, the term 'school of economic thought' falls under the definition established by the methodology of science. However, this has brought a specific problem to light regarding the criteria used for differentiating schools of economic thought.

The literature of modern economic thought offers various classifications of schools. Examples of the synthetic and holistic approach can be found in Snowdon et al. (1995), Landreth - Colander (2001), Perlman (2007) or Chang (2015). ${ }^{3}$ Due to the non-compliance of the criteria described in the text (i.e. the fact that none of the classifications proposed by the aforementioned authors could be directly applied to the study), a new classification was created for the purposes of the study.

The schools could not be limited to one particular field or sub-discipline of economics, and must have made a larger contribution to economic research than simply the application of the new research methods. Furthermore, the fact that the study pertains modern schools of thought required the inclusion of an addi-

2 The group which was also strongly represented in the sample was neoclassical economists $(18 \%)$, as well as those whose approach was rooted in the views of Keynes (19\%). Affiliation with institutional/neo-institutional economics was declared by $7 \%$ of the respondents, with evolutionary economics declared by $5 \%$ and Marxian/neo-Marxian by $4 \%$ of the respondents. At the level of $1 \%$ or lower, behavioural and Austrian/neo-Austrian economics were the least popular schools of economic thought.

3 The usefulness of this kind of classifications in the history of economic thought is further discussed by Peterson - Bean (1998). 
tional criterion, specifying that the potential schools must play a significant role in modern economics and must have originated in (or at least have substantial intellectual roots in) the second half of the $20^{\text {th }}$ century.

As a result, we recognise six schools meeting the above requirements, such as:

- neo-Austrian economics,

- new institutional economics,

- radical economics,

- new Keynesian economics,

- new classical economics and

- post-Keynesianism.

The classification is supplemented with 'eclecticism', based on the assumption that some academic economists could self-identify with the mixed approaches towards economic theory.

Each of the six schools is broad and distinctive enough that it is possible to identify relevant differences between them when applied to the same areas of analysis. For the purposes of our study, we chose four key issues (Table 1), each of which was addressed differently by the six schools. The issues are as follows:

- the dominant actor of the market,

- the need for economic regulation from the government,

- the sources of market economy instability, and

- economic equilibrium in a market economy.

This selection of the issues was primarily determined by the need to find subject matters where the authors could distinguish separable views presented by each of the examined schools of economic thought. Determining these six selected schools and their approaches to the four aforementioned issues enabled formulating substantive questions for the surveyed academic economists. Therefore, the categories of responses presented in Table 1 required deliberate semantic choices; the intention was not only to accurately represent the views of each school of thought, but also to highlight the differences.

The classification of the schools and the descriptions of their positions on the selected issues distinguish our study from the previously mentioned studies conducted in the Western European countries (Frey et al. 2010; Di Maio 2013). One noteworthy difference is that those studies propose a greater fragmentation within the classification of schools of economic thought than our study does. For the purposes of our study, we elected to omit schools, such as behavioural, regulatory, evolutionary, supply-side, monetarist and public choice schools of economic thought. 


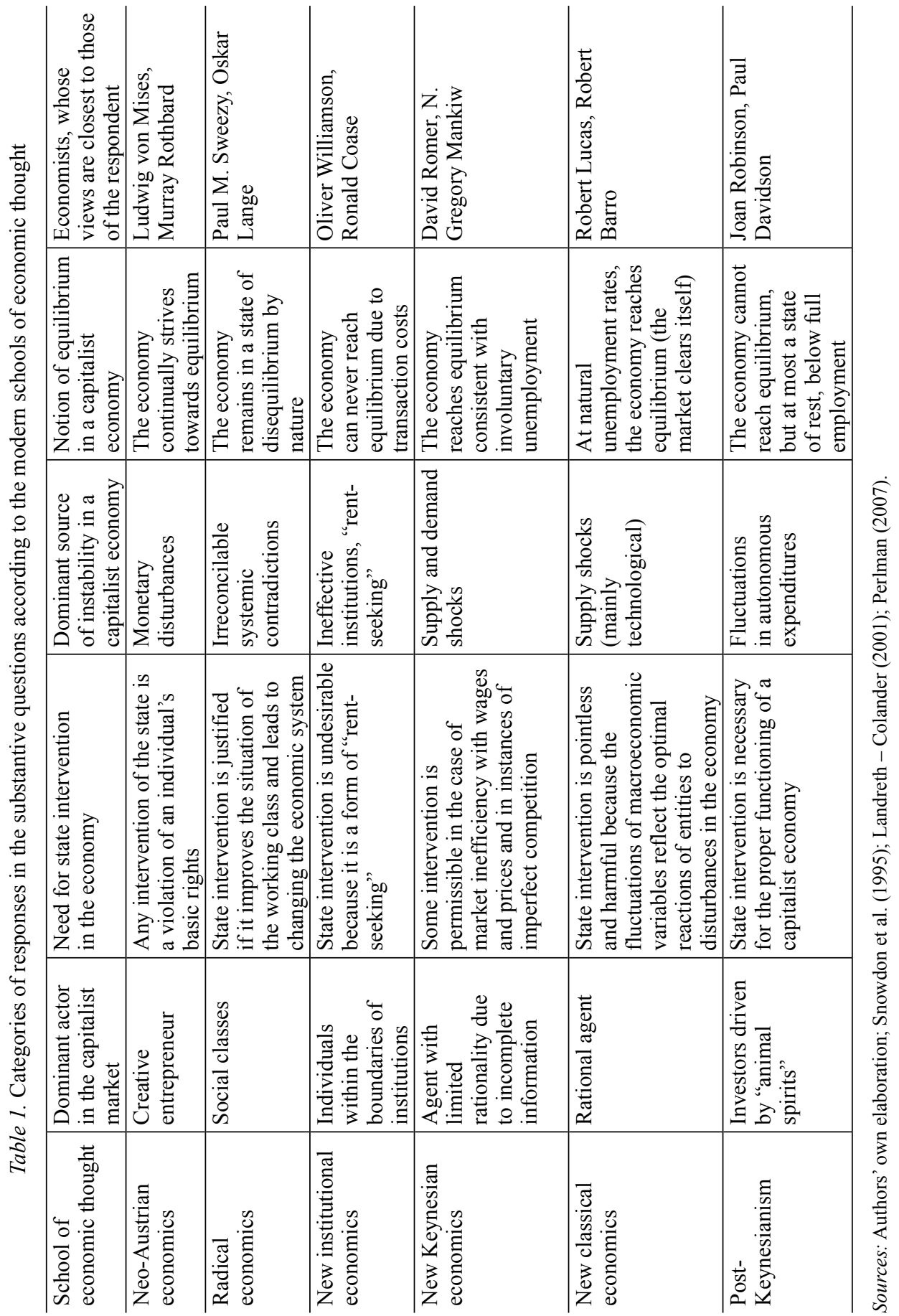


Among other aspects, the two previously mentioned studies also take into consideration the national characteristics of the schools. Specifically, the underscoring of Ordo-liberalism in the German-speaking world and the Sraffian (and neoMarxian) school in Italy, both of which can be simultaneously considered as the national and universal schools of economic thought. From this perspective, the Polish economic thought does not have any national characteristics broad enough to also be considered as universal. In the post-war years, the Polish economics distinguished itself with its reflections on the political economy of socialism. The Polish Marxian economists (particularly Oskar Lange, Włodzimierz Brus, Aleksy Wakar or Edward Lipiński) had formulated far-reaching, original concepts of the operating principles and reforms of a centrally planned economy. However, following the regime change in 1989, their works lost both the importance and the point of reference. The second national characteristic of the Polish economic sciences after 1989 was the analysis of the Polish transformation process - from a centrally planned economy to a market economy - as a potential model for other countries (see e.g. the works of Leszek Balcerowicz, Grzegorz Kołodko and Tadeusz Kowalik). However, this issue is a subject for cross-sectional analysis, to be examined by various economic schools. It is, for instance, being explored by both new classical economics and institutionalism.

When analysing the Polish economics from the point of view of its pioneers, who entered the greater economic consciousness, the role of Michał Kalecki must not be understated. However, his concepts are neither reflected in the course materials commonly used in the Polish universities, nor are they included in economic textbooks. In the Western universities, the works of Kalecki are usually brought up during the macroeconomics lectures and included in textbooks as an element of post-Keynesian (and occasionally Marxian) economics, i.e. the schools that have already been taken into account in the analyses discussed in this paper. Bearing this in mind, it would have been difficult for us to include 'Kaleckian economics' among the recognized modern economic schools, which are already well-known and developed in the Polish academic circles.

We adopted a classification of the schools of economic thought that reflects the modern economic science scene in an aggregated manner and without any specific national focus. It became the basis for our online survey ${ }^{4}$, which was con-

4 The questionnaire consisted of 23 questions (including two open ones), both substantive concerning outstanding scholars who influenced respondents' research interests as well as methods used by the surveyed in their scientific work - and demographic questions. At the beginning of the survey, there were two introductory questions (aimed at - inter alia - attracting respondents' attention to the research project), which concerned the assessment of the contribution of the Polish economics to economic thought in general as well as barriers to the development of the Polish academic economics. Subsequently, the following research problems 
ducted among the economists with a doctoral degree or higher. With our survey, we reached 48 public universities (economic universities, universities and polytechnics with faculties of economics), the faculties of economics of five selected, top-ranked private universities and three scientific research institutes. The information on the purpose of the study and the invitation to participate in the survey was sent to the email addresses of 3,051 academic scientists. ${ }^{5}$ The survey was available on the Internet from June 19th to August 20th 2015. Of those people, $1,293(42.4 \%)$ accessed the survey, and 309 questionnaires were fully completed and therefore analysed (10.1\% of the people who received an email, and $23.9 \%$ of individuals who accessed the survey on the internet).

\section{SURVEY FINDINGS}

\subsection{Characteristics of the respondents}

Among the respondents, men constituted the majority of the sample (61.5\%), while women are only $38.5 \%$ (Table 2 ). The majority of respondents who decided to complete the questionnaires were relatively young, usually under the age of 45 $(58.9 \%)$.

were taken into account: schools of economic thought with which respondents self-identify, assessing which of those schools currently dominate in Poland, views on the fundamental issues differentiating schools of economic thought (the dominant actor of the market, the need for economic regulation from the government, the sources of instability in market economy, and economic equilibrium in a market economy), as well as authority figures accepted by the respondents. The substantive part of the survey was concluded by a question about the most important problems in the Polish economy that require a solution in order to ensure its dynamic development. Finally, the last part of the questionnaire was demographic questions concerning respondents' personal characteristics: gender, age, education, social background, place of obtaining a diploma, place of employment and the region in which it is located, research interests (according to the JEL codes) and participation in internships or scholarships abroad.

5 The list of the individuals who received a request to fill in the survey was compiled through information available on the websites of the surveyed institutions. The total number of individual email addresses to which the survey was sent to was 3,155 . The difference between the number of people included in the research and the number of the questionnaires sent was due to the fact that some respondents were employed in more than one institution.

6 In that period, three reminders have been sent to those who did not respond to the questionnaire and did not declare their will to be excluded from the survey. Also, the heads of academic departments whose employees were in the surveyed population were sent (in the number of almost 400 copies) a specially prepared brochure, informing about the objectives of the research and requesting that such information would be provided to their subordinates. 
Table 2. Distribution of respondents by age and gender (\%)

\begin{tabular}{c|c|c|c}
\hline Age & Total & Women & Men \\
\hline Under 35 & 16.5 & 9.1 & 7.4 \\
\hline $36-45$ & 42.4 & 16.8 & 25.6 \\
\hline $46-55$ & 15.2 & 6.1 & 9.1 \\
\hline $56-65$ & 13.9 & 4.9 & 9.1 \\
\hline Over 65 & 12.0 & 1.6 & 10.4 \\
\hline Total & 100.0 & 38.5 & 61.5 \\
\hline
\end{tabular}

Source: Authors' own elaboration.

The findings point out significant differences between the shares of women on the two extremes of the age range - the group of the youngest female respondents (up to 35 years of age) was over five times larger than that of the female participants who were above the age of 65 . This indicates a change in the gender distribution (an increase in the number of women engaged in scientific activity) among scientists who began their professional life after the economic transformation of 1989 (e.g. Siemieńska 2000).

We made an effort to collect answers about the social background and environment with two direct questions. We wanted to know where the respondent completed their primary education and what was the level of education of their two parents. The surveyed economists mainly came from families of a relatively high level of education, their parents being most likely to have completed higher education (45\%). Only one fifth of the respondents came from families where parents had only primary education. The respondents were most likely to have received their primary level education in cities, primarily large (over 500,000 inhabitants, $37.2 \%$ ) and medium-sized (101,000 to 500,000 inhabitants, $28.2 \%)$. Only one in ten of those surveyed respondents attended primary school in a rural area. These two factors, which together constituted the environment in which the respondents were brought up, allowed them to obtain the social capital they would use at subsequent levels of education and in their professional career. This confirms the assumption of the respondents' inheritance of education (and consequently, social status) from their parents.

The examined group was homogeneous in not only the type of university where respondents obtained their diplomas, but also in their fields of study. An overwhelming majority of the respondents were MA graduates from national public universities $(94.5 \%)$. The remainder graduated from either national nonpublic or foreign universities ( 2.3 and $3.2 \%$, respectively). In terms of faculties, they were most likely to have obtained a degree in economics (70.7\%). However, some respondents obtained their MA diploma in other faculties, such as management, finance and social sciences $(14.9 \%, 8.0 \%$ and $8.0 \%$, respectively). Other 
degrees held by the academic economists included faculties of mathematical science (5.8\%), technical studies (4.9\%), and natural sciences (2.6\%).

The majority of the respondents in the examined group held a $\mathrm{PhD}$ degree $(52.4 \%)$, which is related to the group's age distribution. Additionally, a large share of the respondents held the title of professor (30.1\%). An overwhelming majority of $88.7 \%$ of those surveyed were employees of public universities (the most prevalent category of higher education institutions in Poland), while only $11.0 \%$ were employed in private universities.

The examined group showed a great diversity in their areas of interest (research fields). ${ }^{7}$ However, the study revealed a greater concentration on a few areas in particular: a) economic development, innovations, technological change and growth; b) mathematical and quantitative methods; c) business administration and business economics, marketing, accounting, personnel economics; d) macroeconomics and monetary economics; e) microeconomics (applicable to $20.4-23.0 \%$ of the respondents).

The variable which, as was assumed, can differentiate the surveyed population to a certain degree, was the direct contact with world economics as determined through the questions about the respondents' participation in minimum threemonth internships or scholarships abroad. Nearly half of the respondents $(47.9 \%$ in total, or $35.3 \%$ of the surveyed women and $55.8 \%$ of the surveyed men) had taken advantage of such opportunities. Among them, the largest contributing age groups were found at both extremes, with 36-45 in the lead (28.4\%), followed by those over 65 years of age (21.6\%).

\subsection{Schools of economic thought in the Polish academic economics}

The largest group of the respondents declared to affiliate themselves with new institutional economics (30.4\%). The next most popular schools received almost half of the support as new institutional economics did, those being eclecticism, new classical economics and new Keynesian economics $(16.8 \%, 15.2 \%$ and $12.9 \%$, respectively), as illustrated in Figure 1. However, while the most popular institutional economics is significantly more popular than the second choice (eclecticism) with $p$-value $<0.001$, the $p$-value for the significance of the difference between the second and the fourth popular choice (Keynesian economics) is roughly 0.173 . The respondents who associated themselves with new institutional

With the question regarding fields of research, we used the classification of the Journal of Economic Literature (JEL). The respondents were not limited in terms of the number of responses, and could declare any number of fields of interest. 


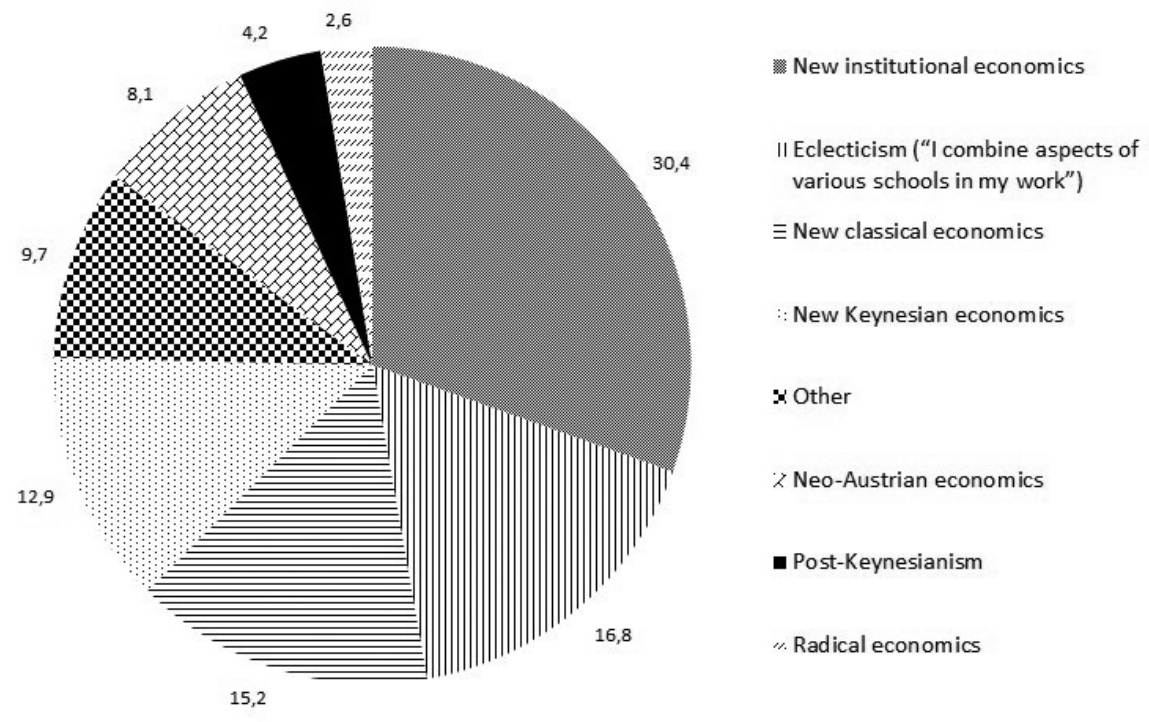

Figure 1. Schools of economic thought the respondents identified with (\%)

Source: As in Table 2.

Note: $\mathrm{N}=309$.

economics overwhelmingly outnumbered 'eclectics' (by 80.8\%), and consisted of a greater share of respondents than the representatives of two main orthodox schools combined (even though the difference is not statistically significant: new classicals and new Keynesians together amounted to $28.1 \%$, compared to new institutionalists, who made up $30.4 \%$ of the group; $p$-value $=0.536$ ). Two additional observations are worthy of note. First, the number of the respondents who declared their affiliation with the neo-Austrian school of thought (8.1\%) was higher than the share of the post-Keynesian and radical economists combined (6.8\%), though the difference cannot be considered statistically significant ( $p$-value $=$ $0.538)$. Second, the new classical economists were more prevalent than the new Keynesian economists ( $15.2 \%$ and $12.9 \%$, respectively), however, the tests again do not provide an evidence for the significant difference $(p$-value $=0.411)$.

In an attempt to establish how the respondents perceived theoretical divisions occurring in economics, they were asked to specify which schools of economic thought they believed to be presently dominant in Poland (Figure 2). ${ }^{8}$ The distribution of the responses to this question differed significantly from the findings of

8 The question was intentionally broad in its nature and it did not indicate precisely the authors' understanding of the term 'dominance'. The dominance of a school may be described in such terms as the share of the representatives of each school in academic circles overall, as well as 

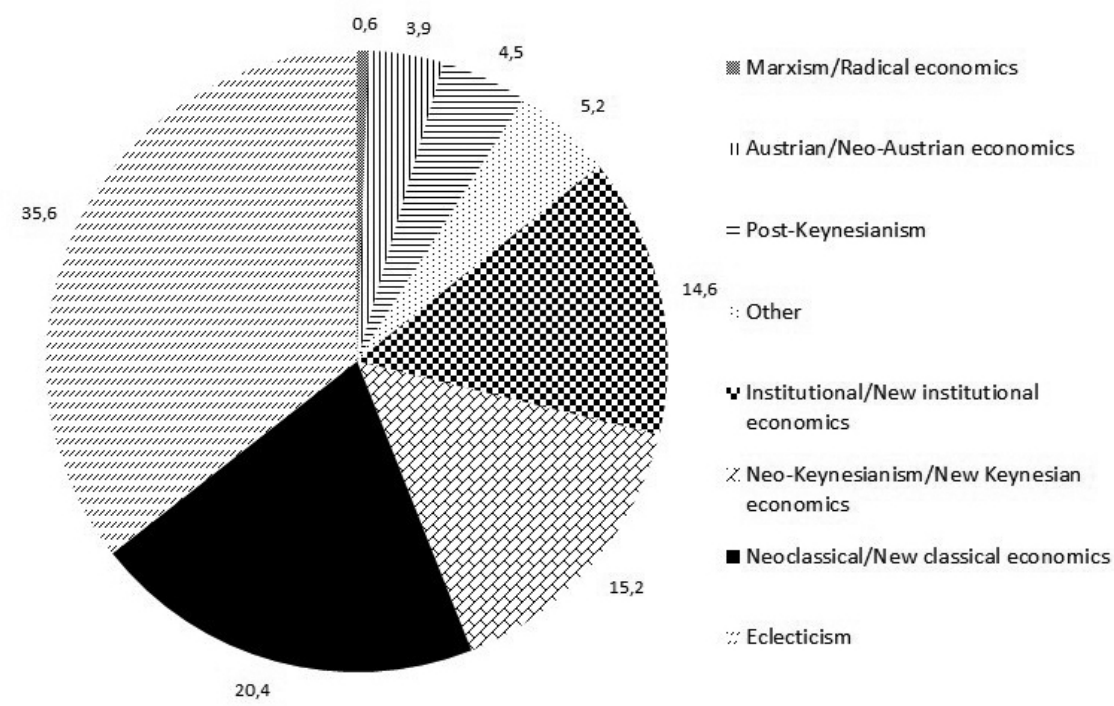

Figure 2. Schools perceived to be dominant in Polish academic economics (\%)

Source: As in Table 2.

Note: $\mathrm{N}=309$. With the question about self-identification, we aimed to establish the affiliation of the economists with the modern schools of economic thought, while with the question regarding the schools' dominance, we decided to give the respondents the opportunity to point to historical trends as well. This accounts for the different (more general) selection of response options.

the self-identification portion of the questionnaire. The most notable part of the respondents were convinced that presently the Polish economics is exhibiting the tendency of combining views of various schools, rather than identifying with one consistent system of thought (35.6\%). Moreover, three schools were mentioned above others: neoclassical/new classical economics, neo-Keynesianism $/$ new Keynesian economics and institutionalism/new institutional economics $(20.4 \%$, $15.2 \%$ and $14.6 \%$, respectively). Only a few of the respondents considered Marxism, Austrian economics or post-Keynesianism as a dominant approach $(0.6 \%$, $3.9 \%$ and $4.5 \%$, respectively).

The respondents' selections of schools of economic thought corresponded with their responses to the open question regarding the methods applied in their scientific work. Almost three out of five respondents declared that they used quantitative methods, while less than two-fifths preferred qualitative methods

the frequency at which these views appear (or the power with which they are articulated) in public discussions (both scientific and political). The aim of this question was not an evaluation of how common the views of each school were, but rather to introduce respondents to the subject matter of the research and gathering emotional and instinctive responses. 
(what is noteworthy, some of the respondents pointed to the use of both). Perhaps surprisingly, 'quantitative methods' was the most popular response among representatives of all schools of economic thought. In the case of some schools, we also observed several interesting patterns: a) the respondents who identified themselves with the neo-Austrian school were most likely to declare preference for the 'deductive' method (including the 'hypothetico-deductive method') $p$-value in the test of the hypothesis that the popularity of the deductive methods is greater than the second most popular option equals 0.061 ; b) those identifying as 'radicals' tended to prefer the literature-focused scientific method (including descriptive and critical analyses of sources) $-p$-value $=0.151$; c) the respondents self-described as new institutionalists most frequently applied quantitative methods $(p$-value $=0.233)$; d those identifying themselves with new Keynesianism preferred theoretical/mathematical models ( $p$-value in the test of the hypothesis that the popularity of quantitative methods is greater than the popularity of the qualitative methods equals 0.007 in this group). These results mostly seem to be in line with the broadly understood methodological profiles of these schools. However, mostly due to the low number of respondents in the samples, the differences in the majority of the cases are significantly different.

\subsection{Internal consistency of theoretical views}

The empirical data illustrated the low internal consistency between the respondents' declared affiliations and their answers to the questions about their views on specific economic issues. The surveyed group expressed eclectic views which were not entirely consistent with those of the schools they identified with; and they would express certain views which varied from (and were often in contradiction with) the theoretical foundations of the schools they associated themselves with (Table 3). The question remains whether this situation stems from a conscious eclecticism that is prevalent in the Polish (and possibly even global) economics, which results in diversified views on many issues despite declarative affiliation with particular schools; or perhaps conversely, the phenomenon is merely a result of the respondents' insufficient theoretical knowledge of schools of economic thought, and perhaps an unintentional attribution of their own views to particular schools.

In response to the question concerning the dominant actor of the market in a capitalist economy, over half of those surveyed (50.8\%) provided answers consistent with Keynesian schools of economics, even though only $17.1 \%$ of the participants declared affiliation with these schools. Interestingly, those self-identifying with new institutional economics were more likely to select the new Keynesian answer 
Table 3. Responses to questions on economic issues according to the specific schools of economic thought $(\%)$

\begin{tabular}{l|c|c|c|c}
\hline $\begin{array}{l}\text { School of economic } \\
\text { thought }\end{array}$ & $\begin{array}{c}\text { Dominating } \\
\text { actor in the } \\
\text { capitalist market }\end{array}$ & $\begin{array}{c}\text { Need for state } \\
\text { intervention in } \\
\text { the economy }\end{array}$ & $\begin{array}{c}\text { Dominant } \\
\text { source of insta- } \\
\text { bility in a capi- } \\
\text { talist economy }\end{array}$ & $\begin{array}{c}\text { Notion of } \\
\text { economic } \\
\text { equilibrium } \\
\text { in a capitalist } \\
\text { economy }\end{array}$ \\
\hline $\begin{array}{l}\text { Neo-Austrian } \\
\text { economics }\end{array}$ & 15.9 & 1.6 & 12.0 & 26.2 \\
\hline $\begin{array}{l}\text { New classical } \\
\text { economics }\end{array}$ & 4.2 & 6.1 & 3.2 & 6.8 \\
\hline $\begin{array}{l}\text { New institutional } \\
\text { economics }\end{array}$ & 13.9 & 3.9 & 33.7 & 11.7 \\
\hline $\begin{array}{l}\text { New Keynesian } \\
\text { economics }\end{array}$ & 30.7 & 50.2 & 22.7 & 3.2 \\
\hline Post-Keynesianism & 20.1 & 23.3 & 1.3 & 8.7 \\
\hline Radical economics & 4.2 & 6.5 & 19.1 & 37.2 \\
\hline
\end{tabular}

Source: Authors' own elaboration.

than the new institutional one ('individuals within the boundaries of institutions'). The new Keynesians and post-Keynesians were the most consistent with their answers - the greatest share of their responses fell under the category which was determined to most accurately reflect the general views of these schools. However, this is most likely a circumstantial occurrence: rather than being an indication of a higher level of theoretical self-awareness among the Keynesians, and this is most likely related to the fact that the response categories, which were characteristic for the 'Keynesian' schools of thought, were the most popular among the surveyed population. It is safer to assume this direction of causality (i.e. from the general 'popularity' of particular ideas to those ideas' strong representation among the representatives of those schools), rather than the opposite.

Regarding the views on state intervention in the economy, the vast majority of the surveyed economists $(73.5 \%$ ) provided answers consistent with the Keynesian schools of thought. The new institutionalists, similarly as with the question regarding the dominant actor of the market, would identify with the new Keynesian viewpoint more often than with the new institutional one. Economic intervention was approved of by the new classical economists as well, and even by several neo-Austrian economists, of which one-third would accept it under certain conditions. The readiness, with which the representatives of various schools pointed to the importance of the state intervention in the proper functioning of the economy (despite the significant differences in the respondents' definitions of interventionism), makes it safe to assume that this view is not a coincidence, but rather a reflection of views which are in fact widely shared by the Polish economists. 
In the case of the question regarding the dominant source of instability in the economy, the largest number of those surveyed (33.7\%) responded in line with new institutional economics, while $22.7 \%$ provided a new Keynesian answer. The predominance of the new institutional views is worthy to note in this context, as is the marked overrepresentation (19.1\%) of responses aligned with radical economics ('irreconcilable systemic contradictions') proportionate to the share of the economists who declared their affiliation with radical economics. This indicates that regarding the views on the functioning of the economy, the surveyed economists showed a noticeable tendency to lean towards the left-wing views. Among the representatives of almost all schools, with the exception of new Keynesian economics, ineffective institutions were one of the two most frequently cited reasons for instability in capitalist economies. Demand and supply shocks were a common choice for the new Keynesians, as well as the new classics and new institutionalists, while 'irreconcilable systemic contradictions' was a response preferred by the new Keynesians and post-Keynesians, in addition to the radicals.

In the case of the question regarding the notion of equilibrium in capitalist economies ${ }^{9}$, the viewpoint of radical economics proved to be the most popular, which asserts that 'the economy remains in a state of disequilibrium by nature' (37.2\%), followed by the view of the Austrian school that 'the economy continually strives towards equilibrium' (26.2\%). Generally, the most prevalent viewpoints (the consensus) among the surveyed Polish academic economists were the belief in the lack of equilibrium in the economy, and a broadly understood support for state intervention.

The responses to the question regarding who the respondents view as authorities and influential figures confirm the earlier conclusions drawn from the collected research data, on the dominance of new institutional economics in the Polish academic economics (Figure 3) ${ }^{10}$ Two of the most popular economic authorities were representatives of the new institutional economic thought (with $p$-value for the significance of difference in their popularity being 0.862 ), and the aggregated responses confirmed the observations regarding the 'conservative' leanings of some representatives of the academic circles. This is reflected through the overrepresentation of neo-Austrian economics in relation to post-Keynesianism and

9 It is worth to note that four responses essentially assumed lack of equilibrium (though all of them stemmed from wildly varying theoretical premises and different dynamics of the process leading to the conclusion), while two of them assumed the existence of equilibrium.

10 Each respondent could select one or two responses from the list of 12 names. They were purposefully selected in such a way that each of the six analysed modern schools of economic thought had two representatives. 


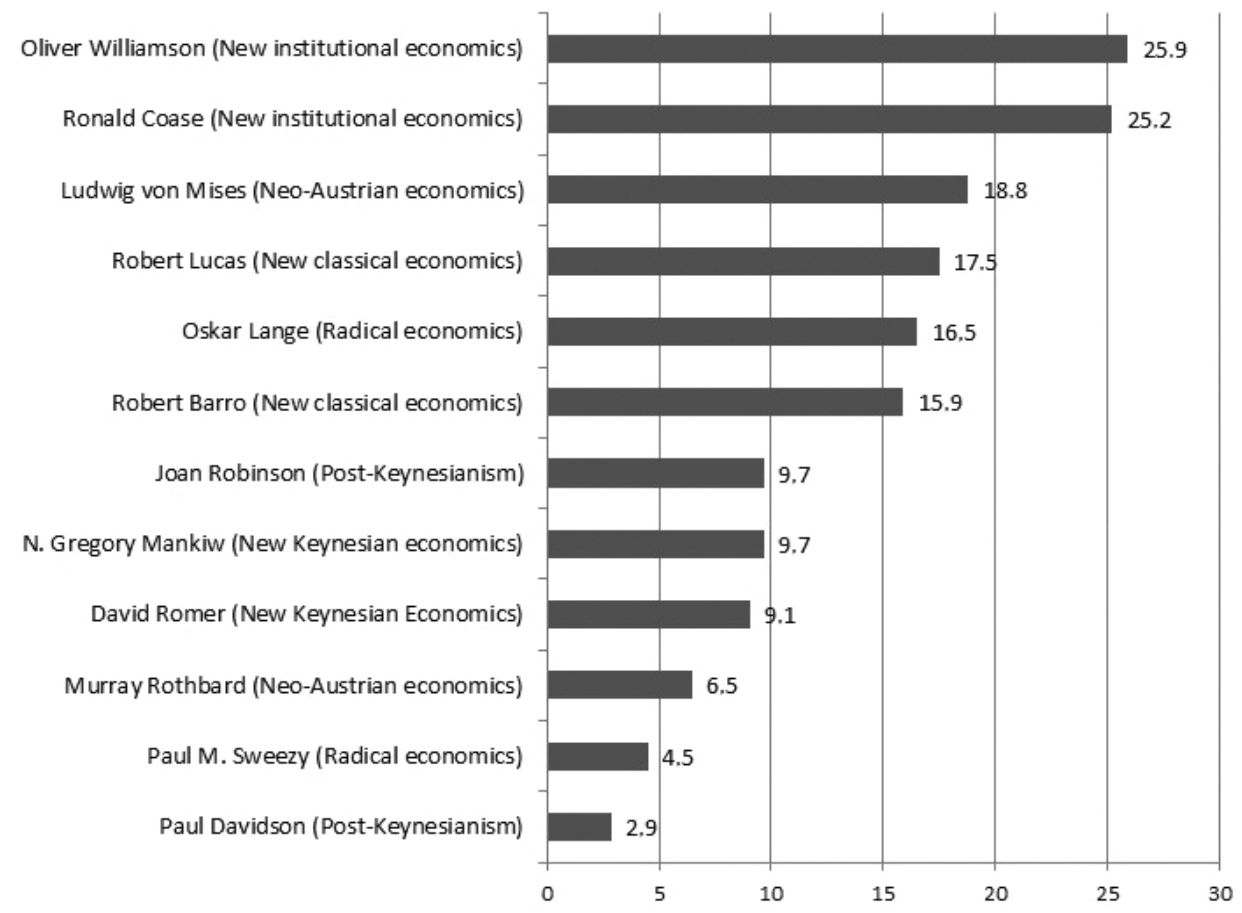

Figure 3. Economists perceived as authorities by respondents (\%)

Source: As in Table 2.

Note: $\mathrm{N}=309$. Since the respondents were asked to select up to two answers, the total number of responses given amounted to 501 .

radical economics on the one hand, and of new classical over new Keynesian economics on the other hand (Ludwig von Mises, the third most popular figure, with the $p$-value for the significance of the difference in the popularity between him and the second Coase being 0.065, and the fourth and sixth place, respectively, of Robert Lucas and Robert Barro; nevertheless the $p$-value in the test of significance between the third von Mises and the sixth Barro was merely 0.357).

Oskar Lange's high popularity requires an in-depth explanation. The original intent behind his inclusion was an intuitive choice for the Polish radical economists. However, it appears that the high percentage of responses favouring this choice, exceeding many times over the declared participation of radical economists in the sample, is most likely not associated with Lange's Marxism. Instead, it is much more plausible that his popularity stems from those areas of his works which serve as an inspiration for the representatives of other schools, such as institutionalism. It is also crucial to note that Lange was the only Polish economist among the response options. He may have been a 'safe' or 'accidental' choice in the case of 
insufficient knowledge of some respondents on the subject of economic theory, when faced with the unfamiliar names of other economic authority figures. ${ }^{11}$

Based on the findings of this study, we can conclude that there is a certain understanding in Polish economics of the network of schools of academic thought, with the caveat that this understanding is rather shallow, such as it is limited to authorities as understood through keywords and does not necessarily extend to in-depth theoretical views. We attempted to assess the internal consistency between the views presented by the respondents on the substantive issues and their self-identification ${ }^{12}$. In each of the four questions regarding views on economic issues, the respondents were asked to select one answer, and in the case of the closed question on authorities to select up to two answers. ${ }^{13}$ Thus, the number of the responses would result in a maximum of six per person. In the case of the question on authority figures, $36.1 \%$ of the respondents named only one economist. As a result, in the analysis for the viewpoint consistency, those survey participants who provided five responses were examined separately from those who provided six. For each of the groups of economists (determined by how they self-identified), the participants' responses were divided into three tiers

11 These conclusions partially corroborate the economists' responses to the open question regarding outstanding (foreign and Polish) economists who exerted the greatest influence on the directions of their scientific work and research interest. (Due to the large number - i.e. hundreds - of responses given to this question, and the resulting significant dispersion among them, we decided to - where possible and using our best knowledge - assign authority figures indicated by the respondents to schools of economic thought in order to get a more concise picture. As a result, we obtained 22 categories including both schools and individual names of some more popular authority figures.) Economists representing broadly defined progressive approaches (categories: 'Marxism/radical economics', 'neo-Keynesianism/new Keynesian economics', 'post-Keynesianism', 'John Maynard Keynes', 'Michał Kalecki', 'Oskar Lange', 'Grzegorz Kołodko') obtained $24.2 \%$ of all responses, while representatives of broadly understood conservative and liberal approaches in the economics (categories: 'Austrian/neo-Austrian school', 'neo-classical/new classical economics', 'monetarism/Chicago school' and 'Leszek Balcerowicz') consisted of $18.9 \%$ of the responses. However, it should be noted that the choices of the Polish academic economists can remain in isolation from a strict identification with the respondents' positions on economic issues. The popularity of the neo-Keynesians/New Keynesians over the institutionalists/new institutionalists - especially in the context of the responses provided by the new institutionalists - may be the reflection of both a relatively Keynesian leaning of the survey participants and a specific eclecticism of new institutionalists.

12 This part of the paper concerns $73.5 \%$ of the examined population, i.e. the respondents who, in the questions regarding self-identification, provided one of the six replies which corresponded to specific schools, as provided in the response options of the questions. It does not include the survey participants who selected eclecticism or responded with 'other'.

13 This was the only case in which we intentionally allowed the respondents to provide one or two answers. The intention behind this choice was to verify the depth of the respondents' knowledge regarding the school the survey participant identifies with. 
of consistency: 'high', 'average' and 'low' depending on the number of responses which were in line with the views of the modern school of economic thought which they had selected. A respondent's consistency was deemed 'high' when the respondents provided around four to six (or four to five) answers correctly aligned with the school they had identified with, 'average' in case where two or three of such answers were given, while one or zero correctly aligned responses would qualify as 'low' consistency.

The key problem was assigning individual positions on each of the discussed issues for the respondents of each particular school of thought. It was assumed that none of the modern schools were monolithic in nature, especially considering the fact that the six approaches selected for the study were determined through broad definitions. For example, radical economics encompasses all roughly related approaches derived from Marxism; 'post-Keynesianism' including orthodox Keynesianism, Kaleckism and Sraffianism; while the category of new classical economics covers the real business-cycle school, among others. It was therefore decided that some questions would allow for certain responses to be accepted as adequately representative of their views, despite not being primarily deemed as belonging to that school of thought, but still considered indicative of other schools of thought. This allowed the surveyed groups for alternative categories of response.

Due to the close relations between new Keynesian economics and new classical economics in their modern form (primarily as a result of similar applied research methods), it was decided that a response in favour of one school would also be considered as a viable alternative response for the other. In the case of the Austrian economics, with the questions regarding the need for state intervention in the economy and economic equilibrium, the new classical economics responses were allowed as possible alternative answers. By the same token, it was decided that the radical economists could also consistently answer two questions by providing responses attributed to post-Keynesianism, and could also point to Joan Robinson as an authority figure. And conversely, when responding to the question on equilibrium in the capitalist economies and the dominant actor in a capitalist market, the post-Keynesians could respond in categories primarily attributed to radical economics. Meanwhile, the representatives of new institutional economics could answer this question with a new Keynesian response, while provide a post-Keynesian response to the question about the need for state intervention in the economy. In the study, we preliminarily labelled these supplementary choices (applying to only one, alternative school) as 'limited eclecticism'. Taking these additional choices into consideration, we carried out a separate analysis of the data (Tables 4 and 5).

The comparison of both variants points to a marked improvement in the number of consistent (with the respondent's school of thought) responses given by the participants when considering limited eclecticism. The share of responses that 
Table 4. The share of consistent responses to questions on economic issues,

by school of economic thought (\%)

(Respondents who provided two answers to the question regarding authority figures)

\begin{tabular}{l|c|c|c|c|c|c}
\hline \multirow{2}{*}{$\begin{array}{l}\text { School of economic } \\
\text { thought }\end{array}$} & \multicolumn{3}{|c|}{ Basic variant } & \multicolumn{3}{c}{ Limited eclecticism } \\
\cline { 2 - 7 } & $\begin{array}{c}\text { Low con- } \\
\text { sistency } \\
(0-1)\end{array}$ & $\begin{array}{c}\text { Average } \\
\text { consist- } \\
\text { ency } \\
(2-3)\end{array}$ & $\begin{array}{c}\text { High con- } \\
\text { sistency } \\
(4-6)\end{array}$ & $\begin{array}{c}\text { Low con- } \\
\text { sistency } \\
(0-1)\end{array}$ & $\begin{array}{c}\text { Average } \\
\text { consist- } \\
\text { ency } \\
(2-3)\end{array}$ & $\begin{array}{c}\text { High con- } \\
\text { sistency } \\
(4-6)\end{array}$ \\
\hline Radical & 25.0 & 75.0 & 0.0 & 0.0 & 75.0 & 25.0 \\
\hline Neo-Austrian & 33.3 & 55.6 & 11.1 & 27.8 & 27.8 & 44.4 \\
\hline Post-Keynesianism & 12.5 & 87.5 & 0.0 & 12.5 & 87.5 & 0.0 \\
\hline New classical & 65.4 & 23.1 & 11.5 & 23.1 & 46.2 & 30.8 \\
\hline New Keynesian & 32.0 & 44.0 & 24.0 & 16.0 & 40.0 & 44.0 \\
\hline New institutional & 31.3 & 50.0 & 18.8 & 21.9 & 45.3 & 32.8 \\
\hline Total & 36.6 & 47.6 & 15.9 & 20.7 & 45.5 & 33.8 \\
\hline
\end{tabular}

Source: Authors' own elaboration.

Notes: Each percentage value represents the share of respondents who declared an affiliation with a particular school of economic thought, who in response to the questions on economic issues and the question on authority figures provided answers consistent with their favoured school.

Table 5. The share of consistent responses to questions on economic issues, by school of economic thought (\%)

(Respondents who provided only one answer to the question regarding authority figures)

\begin{tabular}{|c|c|c|c|c|c|c|}
\hline \multirow{2}{*}{$\begin{array}{l}\text { School of economic } \\
\text { thought }\end{array}$} & \multicolumn{3}{|c|}{ Basic variant } & \multicolumn{3}{|c|}{ Limited eclecticism } \\
\hline & $\begin{array}{l}\text { Low con- } \\
\text { sistency } \\
\quad(0-1)\end{array}$ & $\begin{array}{c}\text { Average } \\
\text { consist- } \\
\text { ency } \\
(2-3)\end{array}$ & $\begin{array}{l}\text { High con- } \\
\text { sistency } \\
(4-6)\end{array}$ & $\begin{array}{l}\text { Low con- } \\
\text { sistency } \\
\quad(0-1)\end{array}$ & $\begin{array}{c}\text { Average } \\
\text { consist- } \\
\text { ency } \\
(2-3)\end{array}$ & $\begin{array}{c}\text { High con- } \\
\text { sistency } \\
(4-6)\end{array}$ \\
\hline Radical & 75.0 & 25.0 & 0.0 & 75.0 & 25.0 & 0.0 \\
\hline Neo-Austrian & 57.1 & 42.9 & 0.0 & 14.3 & 57.1 & 28.6 \\
\hline Post-Keynesianism & 40.0 & 60.0 & 0.0 & 40.0 & 40.0 & 20.0 \\
\hline New classical & 95.2 & 4.8 & 0.0 & 33.3 & 52.4 & 14.3 \\
\hline New Keynesian & 60.0 & 40.0 & 0.0 & 46.7 & 53.3 & 0.0 \\
\hline New institutional & 46.7 & 43.3 & 10.0 & 23.3 & 53.3 & 23.3 \\
\hline Total & 63.4 & 32.9 & 3.7 & 32.9 & 51.2 & 15.9 \\
\hline
\end{tabular}

Source: Authors' own elaboration.

Notes: Each percentage value represents the share of respondents who declared an affiliation with a particular school of economic thought, who in response to the questions on economic issues and the question on authority figures provided answers consistent with their favoured school. 
are highly consistent with the declared school of thought increased significantly, while the percentage of responses characterised by low consistency index decreased. In the case of the respondents who provided two answers to the question on economic authority figures, $33.8 \%$ of the responses were highly consistent with the respondent's self-identification in the limited eclecticism variant, while $20.7 \%$ of the responses indicated a low level of internal consistency. In both variants and in the entire sample, the responses that showed an average level of consistency with the respondents' declared school would always make up roughly the same share of the total responses. A certain observation is worth noting in the case of the participants who provided only one answer to the question concerning the authorities - in the limited eclecticism variant, the share of the answers of low consistency was significantly smaller, while the percentage of those who were characterised by an average or high level of consistency increased.

The representatives of all schools of economic thought who provided only one answer to the question on the economic authority figures provided fewer consistent responses to the questions on economic issues than those who selected two names (Table 5). This phenomenon could relate to the entire analysed sample, both in the basic and limited eclecticism variants. This is particularly visible in the case of the respondents who identified with new classical economics, of whom only $4.8 \%$ provided more than one consistent response to the questions on economic issues under the criteria of the basic variant. The group, whose answers were closest to the average values for the entire examined population, was of new institutionalists and adherents of neo-Austrian economics. It appears that the selection of two names in the question regarding economic authority figures correlates to greater confidence in self-identification, while the selection of only one name points to indecisiveness.

The almost twofold increase in the number of the economists who were highly consistent with their school in the 'limited eclecticism' variant, as well as the significant decrease in the share of the participants characterised by a low level of consistent responses, both confirm the theorized existence of limited eclecticism. However, the fact that even in this variant almost two-thirds of the respondents provided only three consistent responses at most (out of five or six possible) requires an explanation. Two immediate interpretations come to mind: there is either a high level of eclecticism among the surveyed economists, or they have insufficient knowledge of economic theory.

Several interesting findings emerged from the data analysis. The answers of the post-Keynesians and new classical economists in the basic variant diverged significantly from the average values for the entire group. ${ }^{14}$ Most post-Keynesians

14 The number of respondents self-identifying with post-Keynesianism and radical economics was so small that formulating more general views based on these findings would not be justified. 
(87.5\% of the respondents who provided two names in response to the question regarding authorities, and $60 \%$ of the respondents who gave only one) responded with an average consistency with their school, while mostly in the case of new classical economists (65.4\% and $95.2 \%$, respectively), the consistency of their responses to those same questions was low. However, this is only true in the basic variant, with the limited eclecticism variant proving to be radically different. The answers given by the new classical economists were noticeably more consistent with their school of thought (the share of the answers with a low level of consistency in this variant is about three times lower than in the basic variant). Those aligned with neo-Austrian economics showed a major increase in the responses with a high level of consistency (33.3\% of the respondents who provided two names in response to the question regarding authorities, $28.6 \%$ of the respondents who gave only one). In the limited eclecticism variant, they were the group with the most highly consistent responses to the analysed set of questions: over $40 \%$ (28.6\% in the limited eclecticism variant) of them provided between four and six responses correctly aligned with their school. It is also worth noting that in both the variants, the new institutionalists were most likely to answer with at least average consistency with their declared school of economic thought.

Three major conclusions can be drawn from this analysis. First, the group of new classical economists was characterised by strong eclecticism, which pushed its representatives towards the ideas of new Keynesianism. This adheres to the intuitive perception of these two schools, whose representatives tend to focus on the creation and development of mathematical models of general equilibrium. The economists of these schools seem - often rather arbitrarily and under the technical requirements of modelling - to select the theoretical assumptions of new Keynesianism or new classical economics for their models of equilibrium. However, it is difficult to ascertain why the new classical economists tend to support the views of new Keynesianism, rather than vice versa. Secondly, the data on the Polish neo-Austrian economists confirms the earlier findings on the high level of scientific self-awareness and theoretical knowledge of this group. Finally, the new institutionalists proved to be not only the dominant group in the Polish economics, but also a group with highly internally consistent views on the economic issues.

\subsection{Econometric analysis}

We assumed that the economists' views are not only shaped as a part of the process of accepting or rejecting the scientific theories and hypotheses, but are also born from the broader social and socioeconomic processes which form their opin- 
ions as individuals. Such variables, as personal characteristics (e.g. gender, age), social background, economic education (university, MA specialisation) and the person's academic career path (such as obtained scientific degrees) play a significant role. ${ }^{15}$

Consequently, two logit models were estimated. Their functional forms can be denoted as: ${ }^{16}$

$$
\begin{gathered}
y_{i}^{*}=x_{i}^{\prime} \beta+\varepsilon_{i} \\
y_{i}=\left\{\begin{array}{l}
0 \text { if } y_{i}^{*}<0 \\
\text { lif } y_{i}^{*} \geq 0,
\end{array}\right.
\end{gathered}
$$

where:

$y_{i}$-is a binary variable with a value of 1 , if $i$-th $(i=1, \ldots, N)$ respondent identified with a given school of economic thought (new institutional economics in the first model, the 'mainstream' choices of new Keynesian economics or new classical economics in the second model), $x_{i}-$ is a vector of explanatory variables, which includes the factors influencing the self-identification of the economists with particular schools of economic thought, such as personal characteristics (gender, age and place of completion of primary level education), research methods used in academic work and research interests, as well as the schools recognized as dominant in the Polish economics $(i=1, \ldots, N)$,

$y_{i}^{*}$ - is a latent variable (representing agent's propensity to identify with a particular school of economic thought), $\beta$ - is a vector of model parameters,

$\varepsilon_{i}-$ is a (spherical) error term.

Due to the numerous potential variables, the final set was selected through forward stepwise regression. While the general to the specific approach would rather suggest the use of backward stepwise regression, that particular method is

15 The rules of sample selection (individuals holding at least a Ph.D. degree in economic sciences) held inherent limitations regarding the possibility to verify this hypothesis, since the high level of education among the participants weakened the significance of the personal characteristic variables used in social studies. This means that the knowledge acquired over the course of education and research work is just as crucial (if not even more so) in forming their views (see e.g. Domański et al. 2016; Domański 2017).

16 Theoretically, the estimation of a single multinominal logit model would have been methodologically more adequate for the purpose of this study. However, due to the low sample size in pair with high sample size requirements in the multinominal logit model as well as the failure to fulfill the IIA hypothesis in the multinomial logit case, we instead opted to use two separate (binary) logit models. 
not feasible as it would require the inclusion of all the considered independent variables in the most general model at first, while the number of the considered potential independent variables exceeds the sample size.

As indicated by the estimates of model 1 (Table 6), self-identification with new institutional economics shows a positive relationship with the respondents' opinion that either institutionalism/new institutional economics (P5_3) or post-

Table 6. Results of the estimation of Model 1

\begin{tabular}{|c|c|c|c|c|c|}
\hline Variable & Description of the variable & $\begin{array}{l}\text { Parameter } \\
\text { evaluation }\end{array}$ & $\begin{array}{c}\text { Standard } \\
\text { error }\end{array}$ & $\mathrm{z}$ & $\mathrm{P}>\mathrm{z}$ \\
\hline P5_3 & $\begin{array}{l}\text { In your opinion, which school of } \\
\text { economic thought is currently the most } \\
\text { dominant in Polish economics? Institu- } \\
\text { tionalism/new institutional economics }\end{array}$ & 2.06514 & 0.4402471 & 4.69 & 0.000 \\
\hline P17_2 & Age: $36-45$ & -0.7869179 & 0.3731992 & -2.11 & 0.035 \\
\hline P26_3 & $\begin{array}{l}\text { How would you describe your research } \\
\text { field? Which of the following economic } \\
\text { science sub-disciplines are you engaged } \\
\text { in professionally? Mathematical and } \\
\text { quantitative methods }\end{array}$ & -1.097979 & 0.4291805 & -2.56 & 0.011 \\
\hline P26_5 & $\begin{array}{l}\text { How would you describe your research } \\
\text { field? Which of the following economic } \\
\text { science sub-disciplines are you engaged } \\
\text { in professionally? Macroeconomics and } \\
\text { monetary economics }\end{array}$ & -1.180048 & 0.4970678 & -2.37 & 0.018 \\
\hline P17_3 & Age: $46-55$ & 0.9833418 & 0.444832 & 2.21 & 0.027 \\
\hline P18_4 & $\begin{array}{l}\text { Place of completion of primary level } \\
\text { education: City with 101,000-500,000 } \\
\text { inhabitants }\end{array}$ & -0.9406986 & 0.3901066 & -2.41 & 0.016 \\
\hline $\begin{array}{l}\mathrm{P9}-16 \\
\text { methods }\end{array}$ & $\begin{array}{l}\text { What research methods do you employ } \\
\text { in your scientific work? Interdisciplinar- } \\
\text { ity (including philosophy of science and } \\
\text { methodology), methodological eclecti- } \\
\text { cism }\end{array}$ & -2.311924 & 1.090895 & -2.12 & 0.034 \\
\hline P16_M & Gender: Male & -0.7115455 & 0.329376 & -2.16 & 0.031 \\
\hline P26_16 & $\begin{array}{l}\text { How would you define your research } \\
\text { field? Which of the following economic } \\
\text { science sub-disciplines are you engaged } \\
\text { in professionally? Economic systems }\end{array}$ & 0.9677643 & 0.4648876 & 2.08 & 0.037 \\
\hline P19_3_1M & $\begin{array}{l}\text { Education of parents/guardians: Mother: } \\
\text { higher education }\end{array}$ & 0.5530899 & 0.3309185 & 1.67 & 0.095 \\
\hline P5_6 & $\begin{array}{l}\text { In your opinion, which school of } \\
\text { economic thought is currently the most } \\
\text { dominant in Polish economics? Post- } \\
\text { Keynesianism }\end{array}$ & 1.514226 & 0.6725477 & 2.25 & 0.024 \\
\hline const & N/A & -0.47008 & 0.3671396 & -1.28 & 0.200 \\
\hline
\end{tabular}

Source: Authors' own elaboration.

Note: $\mathrm{N}=273$; McFadden's pseudo- $\mathrm{R}^{2}=0.257$; count- $\mathrm{R}^{2}=0.780 ; \chi^{2}$ for the test of joint significance of regressors $=0.000 ; \mathrm{AUC}=0.827$. 
Keynesianism (P5_6) are currently a dominant trend in the Polish academic economics.

The first of the aforementioned relationships is rather intuitive to interpret: the size of and the familiarity with the Polish new institutionalist circles could allow self-identified new institutionalists to interpret - rightfully so - that broadly defined institutionalism is the leading school of thought in the Polish economics. However, it bears importance in mentioning that the majority of the surveyed scientists were actually unaware of the significance of the new institutional economics in Poland.

The second relationship must also be elaborated upon. From the survey results, it is safe to conclude that the representation of post-Keynesian economics in Poland is sparse. Therefore, the respondents' claims (regardless of school of thought, not only those self-identifying with new institutional economics) of the post-Keynesian dominance do not seem to be a result of overestimating the size of the school, but instead of a misunderstanding of the terminology. It appears as though the respondents, who alleged the dominance of 'post-Keynesianism' in the Polish economics, did not have that particular school of thought in mind, but rather all broadly recognised post-World War II economic schools that represented the views of Keynes.

The relationship between the respondents' favoured sub-disciplines of economic sciences (according to the JEL classification) and their tendency to identify with new institutionalism do not appear to form any notable contradictions. The presented model points to a positive relationship between declaring affiliation with new institutional economics and having 'economic systems' (P26_16) as an area of interest, and a negative relationship with 'mathematical and quantitative methods' (P26_3) and 'macroeconomics and monetary economics' (P26_5). The first phenomenon can be explained by the broadly understood attractiveness of institutional economics (including new institutional economics) in Poland as a country having experienced systemic transformation. In the two remaining cases, the methodological differences between new institutional economics and other schools - especially new classical economics and new Keynesian economics - were considerably important: specifically, the highly advanced and rapidly progressing mathematisation of the latter two schools, both of which comprise the intellectual core of macroeconomic orthodoxy. One possible explanation for the popularity of new institutional economics is the school's disinterest with advanced applications of mathematics and the macroeconomic theories based on them, while still remaining in the mainstream discourse of academic economics. Another possibility is that identifying with the school of new institutional economics can possibly provide a certain sense of 'originality', while being free 
from the risk of marginalisation that usually accompanies affiliation with schools that are seen as unambiguously heterodox.

Self-identification with new institutional economics was also found to be correlated with the age of the respondents - a positive relationship in the age category of 46-55 (P17_3), and a negative relationship in the range of 36-45 (P17_2). In order to properly interpret this data, it is important to note that the age category of 36-45 (the most strongly represented age category) was the group with the fewest supporters of the new institutionalism, or $20 \%$ of the participants of that age. At the same time, this age category also boasted the highest share of people identifying with the Austrian economics at $11.5 \%$, where the survey-wide average support for the school was only $8.1 \%$. Thus, it appears that the divergence in choice of economic schools in this age category can be attributed to the time period in which those economists began their studies and careers: the beginning of systemic transformation and the first ten years of the system changes in Poland's economy. This period was characterised by a shift in universities and in economic education towards more mainstream approaches (neoclassical economics, Keynesianism, etc.), and was therefore a time of enthusiasm in the Polish economic academia for the market economy and mainstream economics. In this period, the school of new institutional economics was not yet as popular or recognised as it would become later (as a result of the economic and financial crises that took place at the beginning of the 21 st century, among other things).

With the model examining the relationship between identifying with new institutional economics and place of completing primary level education, the results are unsurprising: a negative correlation with the variable representing cities with 101,000-500,000 inhabitants (P18_4). This implies that there is a strong correlation between self-identification with new institutional economics, and a different response category (other than cities with 101,000-500,000 inhabitants) for this question. Indeed, this is true; as many as $41.5 \%$ of the self-declared new institutionalists completed their primary level education in a city with over 500,000 inhabitants (a percentage surpassed only by supporters of neo-Austrian economics, up to $48.0 \%$ ). Additionally, a positive relationship also exists between identifying with the new institutionalism and the variable denoting the (higher) education level of the respondent's mother (P19_3_1M), which, like the place of completing primary school, indicates the high social background of the participants. Together, these observations lead to the conclusion that new institutional economics is a school often preferred by the economists of higher social status.

The negative relationship between identifying with the new institutionalism and the use of diverse and non-standard research methods (response category 'interdisciplinarity and methodological eclecticism', P9_16 methods) may suggest that the respondents from this school showed particular confidence about 
their choice of research methods. This confidence would allow them to provide more precise responses to the questions regarding their applied methods, though - as previously noted - these methods were quantitative.

Another negative correlation was discovered between the aforementioned variable and male gender (P16_M). It appears that the issue of the applied research methodologies and gender are indeed related - and this is present not just among the respondents identifying with new institutional economics. Closer analysis of the research methods listed by the respondents shows a measurable predominance of one gender over another in certain cases. Only $40 \%$ of the respondents who preferred market (marketing) surveys were men, with women making up the remaining $60 \%$ as an unambiguous majority. Women also constituted the majority of the respondents who preferred 'qualitative' research methods. Men, on the other hand, would more frequently provide such responses as 'theoretical and mathematical modelling', 'econometrics', 'hypothetico-deductive methods', 'experiment' or 'simulation'. The situation described above may indicate a relative preference of women towards 'qualitative' research methods, and of men towards 'quantitative' methods. This would be particularly relevant in the context of the representatives of new institutional economics, as was discussed earlier.

The second model (Table 7) was created in an attempt to determine the factors affecting the respondents' self-identification with the mainstream economics, i.e. new classical economics and new Keynesian economics combined.

First, the respondents who declared a preference for these schools of thought - like most of the surveyed group, but unlike new institutionalists - were not cognisant of the new institutional school's prevalence in the Polish academic economics. As the results of the model indicate, the rejection of this notion could even be considered one of the defining characteristics of the respondents who self-identified with the mainstream economics (P5_3). The respondents across all schools of thought would tend to overestimate the popularity of their school in Poland (compared to the numbers that the results of this study suggest), however, this was especially apparent among those who considered themselves to be part of the mainstream.

As expected, the economists' tendency to identify with new classical or new Keynesian economics shows a positive relationship with their preferences for such research area (sub-disciplines of economic sciences according to the JEL categories) as 'macroeconomics and monetary economics' (P26_5) and 'mathematical and quantitative methods' (P26_3). These results appear to be consistent with the recognised methodological profiles of these schools.

Interestingly, the relationship between the mainstream economists and the sub-discipline of 'history of economic thought, methodology and heterodox approaches' (P26_2), in fact, turned out to be negative. Aside from the redundant 
Table 7. Results of the estimation of Model 2

\begin{tabular}{l|l|c|c|c|c}
\hline Variable & \multicolumn{1}{|c|}{ Description of the variable } & $\begin{array}{l}\text { Parameter } \\
\text { evaluation }\end{array}$ & $\begin{array}{c}\text { Standard } \\
\text { error }\end{array}$ & $\mathrm{z}$ & $\mathrm{P}>\mathrm{z}$ \\
\hline P5_3 & $\begin{array}{l}\text { In your opinion, which school of econom- } \\
\text { ic thought is currently the most dominant } \\
\text { in Polish economics? Institutionalism/ } \\
\text { new institutional economics }\end{array}$ & -1.564767 & 0.5720332 & -2.74 & 0.006 \\
\hline P17_5 & Age: Over 65 & -0.8925401 & 0.4875517 & -1.83 & 0.067 \\
\hline P26_3 & $\begin{array}{l}\text { How would you describe your research } \\
\text { field? Which of the following economic } \\
\text { science sub-disciplines are you engaged } \\
\text { in professionally? Mathematical and } \\
\text { quantitative methods }\end{array}$ & 0.6498796 & 0.3272924 & 1.99 & 0.047 \\
\hline P26_5 & $\begin{array}{l}\text { How would you describe your research } \\
\text { field? Which of the following economic } \\
\text { science sub-disciplines are you engaged } \\
\text { in professionally? Macroeconomics and } \\
\text { monetary economics }\end{array}$ & 0.8412369 & 0.3677391 & 2.29 & 0.022 \\
\hline P18_3 & $\begin{array}{l}\text { Place of completion of primary level } \\
\text { education: Town with 21,000-100,000 } \\
\text { inhabitants }\end{array}$ & 0.735222 & 0.4109922 & 1.79 & 0.074 \\
\hline P9_10 & $\begin{array}{l}\text { What research methods do you employ in } \\
\text { your scientific work? Deduction (includ- } \\
\text { ing hypothetico-deductive method) }\end{array}$ & -1.358645 & 0.6772354 & -2.01 & 0.045 \\
\hline P21_3 & MA specialisation: Management & -0.9751242 & 0.505695 & -1.93 & 0.054 \\
\hline P26_2 & $\begin{array}{l}\text { How would you describe your research } \\
\text { field? Which of the following economic } \\
\text { science sub-disciplines are you engaged } \\
\text { in professionally? History of economic } \\
\text { thought, methodology and heterodox } \\
\text { approaches }\end{array}$ & -1.86265 & 0.5794781 & -3.21 & 0.001 \\
\hline const & $\begin{array}{l}\text { Education of parents/guardians: Father: } \\
\text { higher education }\end{array}$ & -0.9953503 & 0.3182911 & -3.13 & 0.002 \\
\hline N/A & -0.2172539 & 0.2740206 & -0.79 & 0.428 \\
\hline
\end{tabular}

Source: Authors' own elaboration.

Note: $\mathrm{N}=273$; McFadden's pseudo- $\mathrm{R}^{2}=0.171 ;$ count $-\mathrm{R}^{2}=0.773 ; \chi^{2}$ for the test of joint significance of regressors $=0.000 ; \mathrm{AUC}=0.779$.

explanation (people who favour heterodox approaches do not hold mainstream views) and the obvious explanation (the strongly formalised mainstream approach attracts respondents who are interested in exact science and the application of mathematical methods, rather than historical and philosophical studies), it is possible that a third explanation is also valid. Perhaps studying the history of economic thought and methodology, which involves considering different points of view and alternative theories of various schools of economic thought, prevents easily supporting the concepts and findings of the mainstream schools, which tend to ignore the criticisms of heterodox groups and economic methodologists rather than address them. 
The positive relationship between the participants' self-identification with the mainstream economics and the response choice of 'mathematical and quantitative methods', along with the negative relationship with the choice of 'history of economic thought, methodology and heterodox approaches' are both consistent with the negative relationship with the 'deduction (including the hypotheticodeductive method)' (P9_10methods) variable. The respondents, who focused on applied mathematical methods (i.e. not dealing with the issues of the philosophy of science on a day-to-day basis), tended to answer the questions about their preferred research methods with 'detailed' responses (e.g. 'dynamic stochastic general equilibrium modelling'), rather than going with the 'general' option of citing the deductive/hypothetico-deductive method. It is worth noting that the method of deduction was chosen by the neo-Austrian economists much more frequently than by the representatives of other schools.

The negative relationship between identifying with the mainstream economics and the variable corresponding to ages above 65 years does not come as a surprise (P17_5). No doubt, the primary reason for this is the fact that economists in this age group did not have the opportunity to study mainstream theory in their academically formative years, nor did they have the chance to grasp the techniques necessary for studying mainstream economics. This explanation - albeit without the historical component - could also account for the negative coefficient of the variable signifying management (i.e. a discipline which refers neither to the modern economic theories, nor to the advanced quantitative methods) as the respondents' MA specialisation (P21_3).

It is much more difficult to account for the positive relationship between the self-identification of the respondents with the mainstream economics and attending primary schools in smaller towns with 21,000-100,000 inhabitants (P18_3); we can only speculate based on a few premises. First, the Polish cities with under 100,000 inhabitants are very unlikely to have an academic institution providing economic education. Secondly, it can be safely assumed that the place where the respondents completed their primary education, at least for the majority of them, was also the place where most of them completed their secondary education, in short, their hometown. Thus, for most of them, undertaking economic studies would involve moving to a larger city, something social sciences would describe as a manifestation of rising in the social hierarchy. In order for the correlation between this hypothetical sequence of events and self-identification with the mainstream economics to be valid, this group would have to be characterised by a particularly strong need to adapt to the expectations of the majority, while simultaneously being less inclined to challenge the status quo (or in this case, established economic theories) (see e.g. Wagner 2014; Domański et al. 2016; Domański 2017). This hypothesis appears to be strongly supported by the nega- 
tive relation between the respondents' tendency to identify with the mainstream approach and their fathers' higher education (P19_3_2O).

However, it must be emphasised that in the considered models there exists a certain risk of two-way relation between the regressors and the dependent variable in the case of those regressors that serve to identify economic views or related matters. The fact that the data is of cross-sectional character (and not panel) as well as the problems with finding exogeneous instruments for the regressors of economic character other than lags, disables estimation via instrumental variables or GMM. As a consequence, the conclusions drawn regarding the relation between the regressors that describe economic views or preferences and the dependent variable must be taken with caution.

\section{CONCLUSION}

Our study has shown that the school of thought most commonly identified with by the Polish academic economists is the school of new institutional economics. After classifying the schools of economic thought as either orthodox or heterodox, it turns out that nearly half of the surveyed economists (45.3\%) feel associated with heterodox approaches, while slightly more than one in four $(28.1 \%)$ identify with the orthodox schools. The others chose either eclecticism or a response that could not be classified into the other categories. Not only the research team was caught by surprise with these results - the respondents themselves also had inaccurate preconceptions about the dominant schools of thought in the Polish academic economics.

However, this large support for the heterodox approaches is not synonymous with the dominance of leftist thought. Among the heterodox approaches, new institutional economics and the Austrian school proved to be the most popular. Although both schools are considered heterodox, in their modern incarnations, they are actually close to the views of the mainstream economics. They either support the free market to a meaningful degree (neo-Austrian school), or complement the principles of free-market theories as opposed to undermining them (new institutional economics). These schools started becoming especially popular after the financial crises of the $21^{\text {st }}$ century (e.g. Konat - Smuga 2016, an interview with Kwaśnicki in particular). As a result, the 'pure' orthodox approach has lost popularity among economists and its position has been weakened. However, this has not actually lead to a decline in support for the liberal approach in economic theory. Leftist views, on the other hand, have demonstrated considerably low representation. This indicates a shift in values among the Polish economists (e.g. Skarżyńska - Henne 2011). 
Our analysis revealed that at times, the respondents' own views differ significantly from the theoretical tenets of the schools the respondents identified with. The vast majority found state intervention in the economy to be admissible, a characteristic view of the Keynesian schools of economic thought. Regarding sources of instability of the capitalist economy, the response of new institutional economics had the greatest number of supporters, while on the issue of equilibrium, the dominant view was the idea that equilibrium does not exist - the position of radical economics. These views were the most widespread among the survey participants, all of which coalesce into something that one could call a consensus among the Polish academic economists.

Our research also provided further insight into the true eclecticism of the economists' professed views. According to the survey, the academic economists are, in fact, not entirely consistent with their self-proclaimed theoretical approaches of choice. This could be an indicator of either the aforementioned eclecticism of their scientific views, or of insufficient theoretical knowledge.

The survey confirmed that gender and age are two significant variables that differentiate between the schools of thought. Interestingly, among the supporters of the new institutional economics there is a measurable prevalence of women over men, while the Austrian school exhibits an opposite tendency. Like gender, the respondents' age was also correlated with the choice of the school of economic thought. The largest share of the supporters of new institutionalism was noted in the group of the participants aged 46-55, and the smallest among the respondents aged $36-45$.

The views of the latter group should be paid special attention to in the context of the future of the Polish academic economics, since in the upcoming years, the curriculum of economic higher education will be largely determined by the people from this age category. If their preferred schools of thought are of any indication, the school of new institutional economics could lose its current standing, with pro-market views becoming the dominant position among the economists in Poland. This indicates a strengthening of the position of liberal views in the Polish economics in the near future.

Since the mid- $20^{\text {th }}$ century, western economics have witnessed very dynamic intellectual progress, and a far-reaching segmentation and professionalisation. Both processes have been assimilated by the Polish academic economists at an accelerated pace, but this breakthrough has occurred at the expense of weakening the interest in pure economic theory, research methodology and the history of economic thought. The surveyed academic economists had a highly critical view on the contribution of the Polish economic sciences to global academic eco- 
nomics. ${ }^{17}$ They were also convinced of the existence of numerous barriers against the development of the field in Poland, especially pertaining available financial support (insufficient funds allocated to the development of science in the state budget, and the system of awarding grants and financing scientific researches). As a result, the Polish academic economists have followed the development of world economics, while contributing little of importance to it themselves. This is the prevailing view among the academic economists.

The upcoming decades will show whether this field of the Polish academia will still largely be a mere reflection of the trends and tendencies around the world, or will Poland begin providing larger creative contributions to the development of global economics.

\section{REFERENCES}

Aiginger, K. - McCabe, M. - Mueller, D. C. - Weiss, C. (2001): Do American and European Industrial Organization Economists Differ? Review of Industrial Organization, 19(4): 383-404.

Alston, R. M. - Kearl, J. R. - Vaughan, M. B. (1992): Is There a Consensus among Economists in the 1990s? American Economic Review, 82(2): 203-209.

Chang, H. J. (2015): Economics: The User's Guide. New York: Bloomsbury Press.

De Benedictis, L. - Di Maio, M. (2011): Economists' View about the Economy. Evidence from a Survey of Italian Economists. Rivista Italiana degli Economisti, 16(1): 37-84.

De Benedictis, L. - Di Maio, M. (2014): Schools of Thought and Economists' Opinions on Economic Policy. Eastern Economic Journal, 42(3): 1-19.

Di Maio, M. (2013): Are Mainstream and Heterodox Economists Different? An Empirical Analysis. American Journal of Economics and Sociology, 72(5): 1315-1348.

Domański, H. (2017): Wpływ pochodzenia społecznego i czynników merytokratycznych na kapitał społeczny (Effect of Social Origin and Rule of Meritocracy on the Social Capital). Studia Socjologiczne, 227(4): 147-163.

Domański, H. - Federowicz, M. - Pokropek, A. - Przybysz, D. - Sitek, M. - Smulczyk, M. Żółtak, T. (2016): Ścieżki edukacyjne a zdolności i pozycja społeczna (Effects of Social Origin and Abilities on Educational Choices). Studia Socjologiczne, 220(1): 67-98.

Frey, B. S. - Humbert, S. - Schneider, F. (2010): What is Economics? Attitudes and Views of German Economists. Journal of Economic Methodology, 17(3): 317-332.

Fuller, D. - Geide-Stevenson, D. (2003): Consensus among Economists: Revisited. Journal of Economic Education, 34(4): 369-387.

Karpiński, J. (2006): Wprowadzenie do metodologii nauk społecznych (Introduction to the Methodology of Social Sciences). Warsaw: WSPiZ.

Klein, D. B. - Stern, C. (2006): Economists Policy Views and Voting. Public Choice, 126(3-4): 331-342.

17 Nearly $55 \%$ described it as 'small', $16 \%$ as 'none', $23 \%$ as 'average' and only approx. $6 \%$ as 'considerable' or 'great'. 
Konat, G. - Smuga, T. (eds) (2016): Paradoksy ekonomii. Rozmowy z polskimi ekonomistami (Paradoxes of Economics. Conversations with Polish Economists). Warszawa: Wydawnictwo Naukowe PWN.

Landreth, H. - Colander, D. C. (2001): History of Economic Thought. $4^{\text {th }}$ ed., Cincinnati: SouthWestern College Pub.

Perlman, M. (2007): The History of Ideas and Economics. In: Samuels, W. J. - Biddle, J. E. Davis, J. B. (eds): A Companion to the History of Economic Thought. Malden: Blackwell, pp. 634-654.

Peterson, D. - Bean, J. C. (1998): Using a Conceptual Matrix to Organize a Course in the History of Economic Thought. Journal of Economic Education, 29(3): 262-273.

Piech, K. (coordinator) - Janicki, F. - Kropidłowski, D. - Trziszka, Z. - Gaj, E. - Lewandowski, M. (2014): Rozwój oraz polityka gospodarcza i społeczna Polski. Ogólnopolskie badanie ankietowe opinii ekonomistów (The Development of Economic and Social Policy of Poland. National Survey of Economists' Opinion). Warsaw: SGH.

Siemieńska, R. (2000): Women in Academe in Poland: Winners among Losers. Higher Education in Europe, 25(2): 163-172.

Skarżyńska, K. - Henne, K. (2011): Lewicowość-prawicowość autoidentyfikacji politycznych a przekonania i kapitał społeczny - perspektywa psychologii politycznej (Effects of Beliefs and Social Capital on Left-Wing and Right-Wing Political Self-Identification from the Political Psychology Perspective). Studia Socjologiczne, 201(2): 85-108.

Snowdon, B. - Vane, H. R. - Wynarczyk, P. (1995): A Modern Guide to Macroeconomics: An Introduction to Competing Schools of Thought. Cheltenham: Edward Elgar.

Wagner, I. (2014): Kariera naukowa w Polsce. Czy obecny model sprzyja wyłanianiu i awansowaniu 'najlepszych' naukowców? (Scientific Careers in Poland. Is the Current Model Conducive to the Selection and Advancement of the 'Best' Scientists?) Przeglad Socjologiczny, 63(3): 39-65.

Whaples, R. (1995): Where Is There Consensus among American Economic Historians? The Results of a Survey on Forty Proposition. The Journal of Economic History, 55(1): 139-154.

Whaples, R. (1996): Is There Consensus among American Labor Economists? Survey Results on Forty Propositions. Journal of Labor Research, 17(4): 725-734.

Whaples, R. (2006): Do Economists Agree on Anything? Yes! Economists'Voice, 3(9): 1-6.

Whaples, R. - Heckelman, J. C. (2005): Public Choice Economics: Where is there Consensus? The American Economist, 49(1): 66-78. 